\title{
Devils' barrier: faces that look at the visitor from above
}

Keywords: rupestrian drawings, humahuaca valley, devils' barrier, mythology, rock art

\section{Introduction}

The site Devils' Barrier (Tranca de los diablos) is in the Andean region of Argentina. What draws one's attention is the inaccessibility of the paintings: as in other places height and perspective were controlled by the artist. The motives are red painted on a white sandstone wall and are easily visible from below. This wall has a base of 450 meters by 2 meters wide; situated on a steep $50^{\circ}$ slope it is 12 meters above a stream with good fresh water. The wall has 13 faces painted on it and they look towards the Northwest, in crimson red. They have different number of hairs and variations in the features, as well as in the shape of the mouth, the outline of the face and the presence or absence of a nose. The local people fear these "devils" (diablos) and maybe that is the reason for the good conservation.

The rupestrian drawings are in a path which communicates with the altiplano (Puna). On arriving at the place called Devils' Barrier the valley is narrow supposing a real barrier for the cattle. It is common in these narrow places (angostos), near water springs, to find evidence of prehistoric human activity. The only figures that are not faces in common with the paintings are a human being and some camelidae (llama). This confirms the use of the path and the river bed by caravans communicating Humahuaca with the high plateau. Near a loose block of stone, also with painted faces, an archaeological excavation has been carried out: the only niveau found gave 1290 year AD (760 $\mathrm{BP})$ which means that the paintings could belong to the Humahuaca
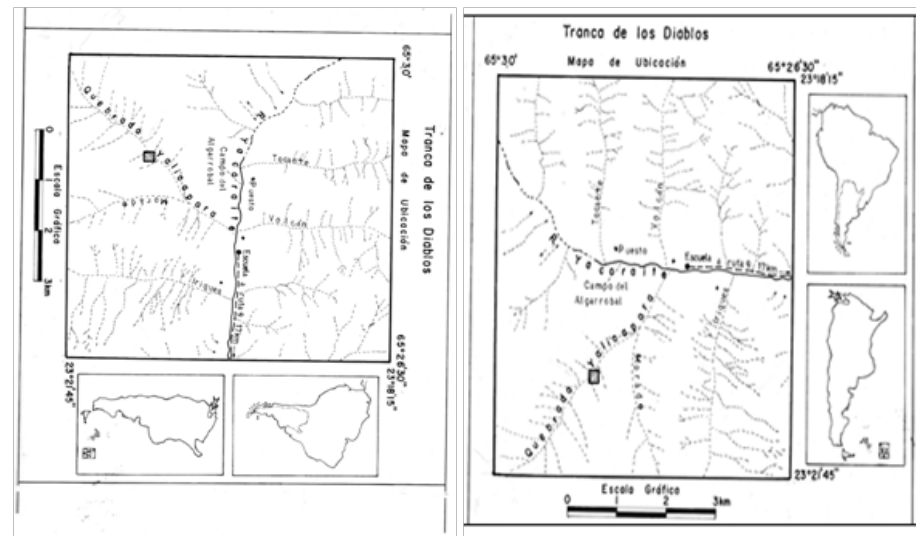

Figure I The main wall, one can see the section $B$, each face has a diameter of

With each new discovery of a site with rock art, the archeologist's interest to catalogue it, culturally and chronologically, is renewed. This fact is intensified because rock art provides a lot of data concerning many instances of the aboriginal daily life which are only poorly recovered through excavations. The most striking example and taken from our Quebrada (valley) of Humahuaca, is the Humahuaca Culture. They decorated the pottery with very simple black lines, very rarely white, but in contrast there are places with rock art very rich is motives: only through these representations could the various facts
Volume 2 Issue 3 - 2017

\author{
Alicia A Fernández \\ Art Space Nicasio Fernández, Argentina
}

Correspondence: Alicia A Fernández,Art Space Nicasio Fernández,Argentina, Email aliciana04@hotmail.com

Received: June 27, 2017 | Published: December 22, 2017

Culture from a period before their contact with the Incas. Devils' Barrier is unique in its striking motifs and does not offer many points of comparison with other known sites in the Humahuaca Valley. The absence in Devils' Barrier of scenes of battles and confrontations (the so called "wars' Epoch" in the 1200 AD of the Humahuaca Region) confirm that Aesthetics and mythology had for the artists of this site, a primordial place.

Pre-historians dedicated to the Andean region of Argentina surmise that the beginning of rock art is somewhere about 4000 years BC, though this is a difficult point to prove with exactitude. Apparently rock painting was prior to rock engraving and in this order, abstract art (dots, zigzag, dragging, impressions of hands, etc.) precedes the naturalistic representation of cametidae (llamas, vicuñas and guanacos) and human figures (Figures 1-4).

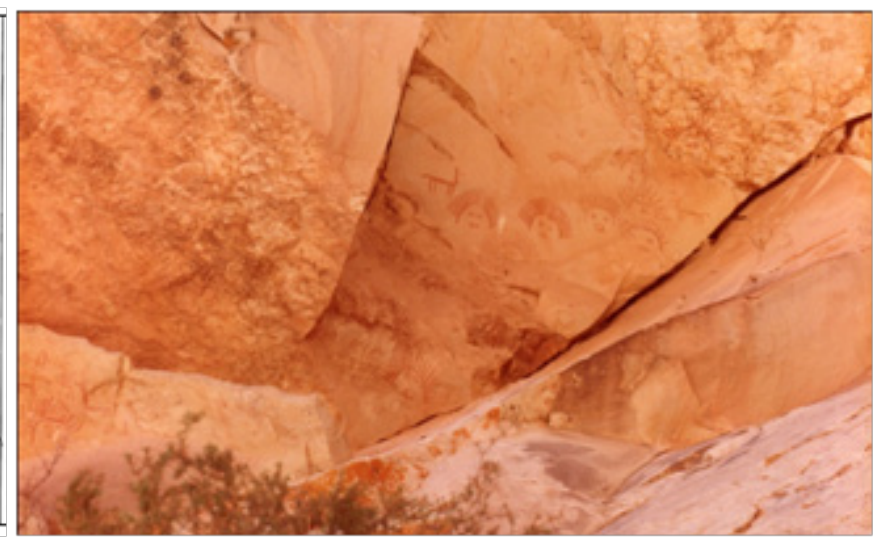

\section{round $28 \mathrm{~cm}$}

related to the daily life of the Humahuaca, such as clothing, metal tools, cattle, cattle marking, confrontations with other tribes or with the Spaniards, etc. be confirmed.

Northwest Argentina rock art begins in pre-ceramic times and continues throughout the farming and pottery age and it also appears at the time of the Spanish conquest. In many articles, ${ }^{1-4}$ I explained how, in very isolated places in the Puna (altiplano), stone engravings with motives of cattle marks, letters, "devils", human faces, Christian 
crosses, etc. still continue. One of the greatest enigmas, which have not been solved in South America, are the pigments used to paint the rock, which have proved to be so strong and adherent. The colors I have more frequently found were red (in all its shades) black and white, very rarely blue, green or yellow. It has been possible also to seriate the appearance of colors in the chain of the time: red seems to be the oldest, followed by white, black being somewhat more recent. Green and blue lacks antiquity.
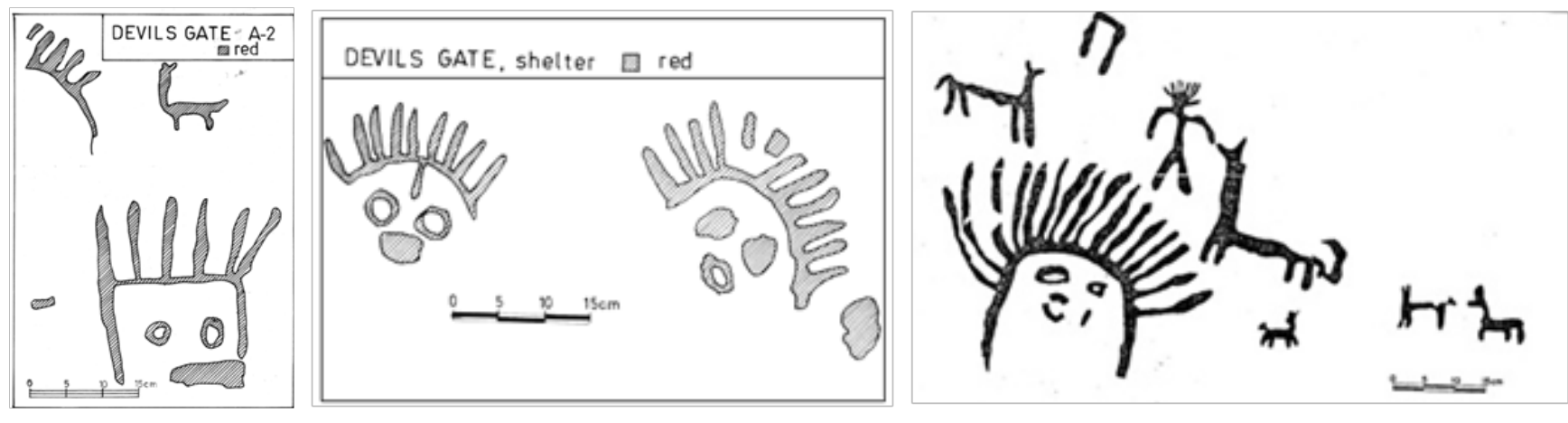

Figure 2 Isolated piece of rock near the section A of the main wall.
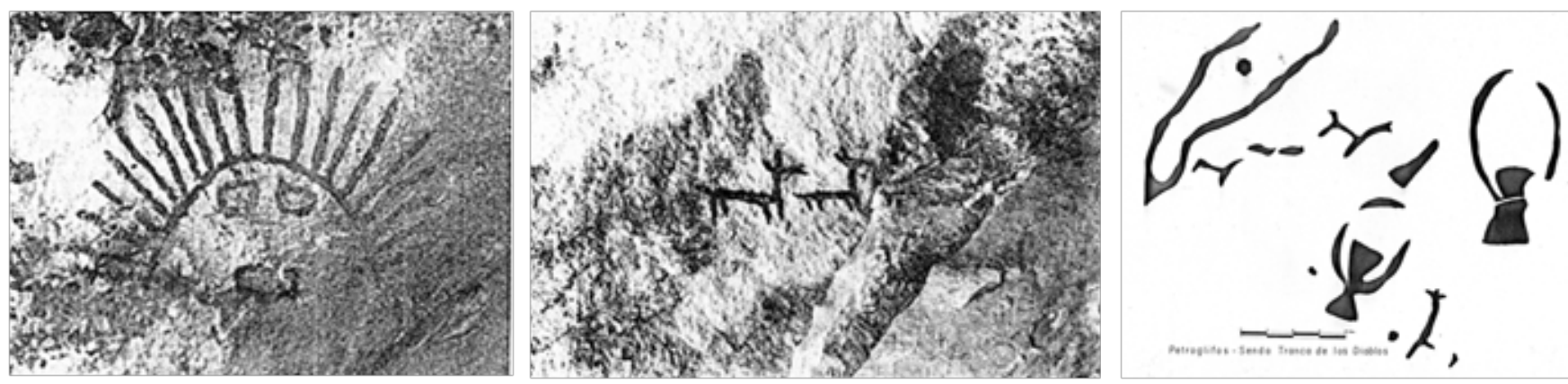

Figure 3 Gravures in Devil's Gate.
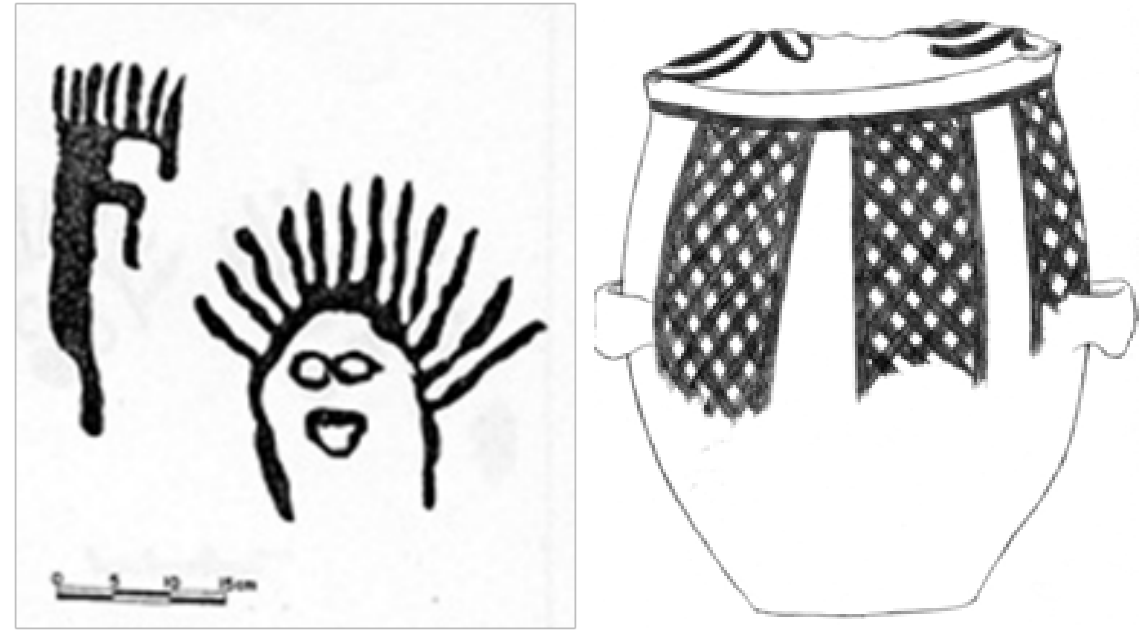

Figure 4 The typical ceramics of the Humahuaca Culture.

Another enigma is the height in which some of these drawings have been made. In some caves and walls, they are in inaccessible places which make think that either the level of the ground has changed or scaffolding was used. Nevertheless, the facts of high and distance were perfectly dominated by the primitive artist and in general the highest drawings are the biggest, the strokes are wider, easily visible from below. In Northwest Argentina the good preservation of paintings is correlative with the degree of isolation in which they are found. The farther they are from highways and motor roads, the more secure they are from irresponsible visitors who wish either to take away a piece

of the prehistoric frieze, or write over it names, dates and initials. On the other hand, it is very difficult for the national and provincial authorities to protect these sites as their location is out of the radius of the villages and frequently are lonely places with not even a dwelling in the surroundings. The great urgency of the archeologists facing this problem is to record as soon as possible all these instances of rock art.

\section{The devils of volcande yacoraite}

In the heart of the Valley of Humahuaca and in the best known part, where pre-historians felt they could no longer find any new remains, I 
made the discovery. For more than thirty years I have been following all the cultural manifestations situated on the western border of the Quebrada of Humahuaca, where one can observe the transit from the valley to the Puna. It was on this western border where my team founded the best caves with many pre-ceramic cultures. If one can compare, the western border of the Argentine Puna it is somewhat like Tamaulipas in Mexico, with equal importance to the archeologist. In the winter of 1983, when at last the mudflows had dried up and the precarious road which took us near the site was transitable, we were able to reach the place. We owe all this to the mayor of Tilcara, Mr. Washington Arroyo, who went with his truck to a place very near the paintings to build a small rural school.

We covered $17 \mathrm{Km}$, along the mudflow of the torrential (in summer) Yacoraite river, always due West. We reached the school, which was unfortunately still in construction. The children used a ruin which is threatened to be washed away by the river next summer. In the little school of Volcán de Yacoraite, we met the people in charge, the Velázquez family, to whom we owe everything we consequently discovered.

The old school and the new one are built on the ruins of an extent "antigal (name under which the abandoned Indian villages are known in the district) some 500 - 700 year old. Places near freshwater springs as this one are reoccupied again and again. On the other side of the river, the Velázquez family has their fields, always threatened by the mudflows and a series of rooms which shelter the family as well as the casual visitor. This was our case. They have a small chapel in which they keep all that is necessary for religious ceremonies, among other things the big Andean trumpet or "erque". In a family with many children, there is always one of them willing to take you to the place of the paintings. Places with ancient remains raise certain fears in the natives and because of this they are very respectful and would never damage them.

When we asked about the famous "paintings" they agreed to accompany us: one hour and a halfs walk in a SW direction, climbing up the valley of Yalicapora, which is a road towards the altiplano. The Velázquez know this valley perfectly, as in the upper part, they have what they call their "estancia": that in to say, a precarious house and many corrals, sheep and goats. During certain times of the year they rotate, either they live in the high part or go down to Volcán of Yacoraite, according to where there is natural pasture to feed their goats and sheep. This moving is done either on foot or on donkey. The spot where the paintings are called Tranca de los Diablos (Devil's Barrier). Here, the valley is so narrow that some thorny bushes placed across the path suffice to stop the animals from going into another property. These places of extreme narrowness are called "angostos" (narrows) or "trancas" (barrier, gate). The Indians also know and venerated these narrow places and there is rock art almost always associated to them. A slope more than $1000 \mathrm{Ms}$ high and a journey of $5 \mathrm{Km}$ along a very stony and narrow river bed obviously prevented us to go by car.

\section{Legends about devil's barrier}

In spite of their friendliness the Velázquez were rather reluctant to take us for the second time, with excavating equipment, to the site of the paintings. This was due to a generalized legend according to which ascending the Quebrada of Yacoraite and then turning left where the Devil's Barrier, 40 loads of gold is were buried by the Spaniards who were bringing it south from Perú. Caught unaware by the War of
Independence, they hid these treasures half way, where they remain to this day. Another version of this legend says that the treasure belonged not to the Spaniards, but to some bandits called Varela, famous in all the North of the Argentine, who towards 1850 pillaged the villages and buried the loot to come back for it later. ${ }^{5}$ This wealth of legends, with very little historical basis explain why a treasure hunter dug a large pit, just at the foot of a rock shelter, very near the painted "devils", the only deposit which would have given the archaeologist any concrete facts on the chronology of the paintings. Of course, the looter did not found everything of interest to him and thrown pottery sherds and stone chippings lie around in disorder. We took advantage of all this and also picked up many samples of charcoal for radiocarbon dating.

\section{Geology of the site and other geographical and metric facts}

"Devil's Barrier", better known under the name of the nearby school, "Volcán de Yacoraite", is situated $23^{\circ} 21$ South and $65^{\circ} 29^{\prime}$ west. At this point and all along the western border of the Puna, the Quebrada of Humahuaca acting as a basin, the geological formations Lecho, Yacoraite and Pirgua (Mesozoic) appear. At the site of the paintings, the transition between the stratification of calcareous whitish sandstone (Yacoraite) and pink sandstone (Lecho) can be seen. The most sinking paintings are found in a wall of whitish sandstone. They face North, $12 \mathrm{Ms}$ above the level of the stream and 3640 m.a.s.l. The main wall has a base 450 meters by 2 meters wide: situated on a steep $50^{\circ}$ slope juts out. The pictures in this wall are only accessible in the lowest part.

Besides the main wall, which has 13 painted faces, all bright red and hairy, there is an unattached rock also with paintings, the shelter I mentioned before, with more blurred paintings of the same style and finally a rock over the path which has a llama painted underneath. Each one of these faces has a base of 25 to $28 \mathrm{Cm}$ and a high of 12 to $20 \mathrm{~cm}$; they coincide in having 15 to 21 "hairs" each. The faces vary in the gestures and the trickling of the paint is very interesting. Needless to say, the paintings are high enough to be inaccessible. On the very narrow path along which one reaches "Devil's Barrier", but still in the pink sandstone formation, we have found a rock with gravures, which with all certainty have same age as the camelidae motive.

\section{Culture and age}

These paintings belong to the Humahuaca Culture, a people that lived in this valley between 1100 and 1500 A.D. At least the pottery recovered at the shelter shows the style peculiar to the Humahuaca Culture and the C. 14 dating confirm this: 1290 A.D. (Hv. 12541). Anyway, "Devils' Barrier" is unique in its motifs and do not offers many points of comparison with other known sites in the Andean region and the well known Quebrada de Humahuaca.

\section{Debate with that archaeologists convinced that around the I 200 AD there was a real "Warriors Era" in the auebrada de humahuaca}

The principal archaeologist in this way is A Nielsen. ${ }^{6}$ He says: "Towards the end of the first millennium AD a period of unrest and confrontation among groups which brought significant changes in society began. This process forced the people of the Quebrada de Humahuaca to live in large, clustered and fortified villages consolidating at the same time a hierarchical social order. Without giving up the abstract designs, the rock art of this period emphasize two 
figurative motifs: the human being and the llama. People are shown frontally or sideways and significant effort is put in depicting details of their attire-robes, anklets, cephalic or dorsal feathered ornaments, caps and the objects they hold -spears, chest plates, axes, bows and arrows. The authors were clearly interested in showing the social and cultural identity of the individuals who are persons of high rank and probably warriors, taking into account the nature of their emblems". Nothing of the enumerated elements is present in Devil's Barrier. There aren't also the cited "abstract motifs" (geometric designs) that always are associated in the panels of the Humahuaca Culture.

\section{An art of farmers engaged in agriculture and livestock management?}

The only explanation to the simplified faces of our site is that it was there a religious place to held rites in relation to water: because it seems that at $900 \mathrm{AD}$ began a long period of droughts. This climatic phenomenon must have severely affected the people in a large area (from NW Argentina to Perú) where the farming success of farming and herding was closely dependent on rainfall. It is possible that in this situation a group of artists- priests of Humahuaca ethnic culture moved to the narrow with fresh water today named Devil's Barrier to held there ceremonies.

What is to criticize in the position of archaeologists like Nielsen is the estimation of a long distance influence from Perú in that time. He thinks that "The warriors Era" in Humahuaca is similar (and associated) to the so called "Auca Runa Era" of Guamán Puma de Ayala , the mestizo priest who at 1600 AD wrote his " Nueva Crónica y Buen Gobierno" to justify the introduction in the Cuzco Region of the Incasic Culture. Guamán Poma de Ayala considered that before the Incas there was one Edad ("Age") of insecurity and inequalities. More precisely there was the forth Age: The fifth signalize the benefices of the introduction of the Inca.

One must recognize that at the $1200 \mathrm{AD}$ the Pucara (pucara=fortified village) consolidates in Humahuaca like in Andean Perú and that the same Guamán Poma speaks from warriors fortified in pucaras (the same quichua word is common in Argentina, Bolivia, Chile and Perú to design fortresses). To understanding rock art of Devil's Barrier theories based in the ethno history aren't useful. The indirect relation with climatic changes is to be encouraged. But the special choice of motifs done by the artists and the altitude indicating that rock art was intended for audiences who are seeing it from some distance away, collocate the site close to religious objectives. With the difficult, we don't know anything about the ancestral religion of the Humahuaca people. Centered at Humahuaca, one can't dispose of accounts of the first conquerors (or from missionaries) about the ideology of the ancient Humahuacas.

To help to reinforce the practical value that aesthetics and rock art had to these peoples immersed in a mythopoyetic conscience ${ }^{7}$ one can say that today, 800 years after, the water cult in the Quebrada and in NW Argentina is already held .In the Andean part of Jujuy in the form of clay camelidae and sheep statues collocated near or at water springs. ${ }^{8}$ Both, the actual inhabitant and the prehistoric one had to venerate the fresh water springs and because of this these places same to be good to "receive art" in the form of clay sculptures today and like painted rock art in the past. Why the thirteen faces with the erected "hairs" (like suns) painted in red remain as a question. Also the variations in the features, the main artistic motives described are not exposed to weather conditions and are inaccessible. But the presence of the path speaks that the site was perceived not only as an ideological resource, but also as a political one and its access was important to control. Hierophanies are a feature of the landscape for all people. Pilgrims regularly go to Ayers Rock, Lourdes and Mecca rather than any other place because of the indefinable but immensely potent spiritual qualities those places exemplify", says S Ouzman. ${ }^{9}$ Aesthetic appreciation plus religious emotion in times of drought are easy to confirm in the narrow path of Devils Barrier that is very near from sprigs. ${ }^{10-12}$

\section{Acknowledgements}

None.

\section{Conflict of interest}

Author declares that there is no conflict of interest.

\section{References}

1. Distel FAA. Un caso de pervivencia del arte rupestre en la provincia de Jujuy, Argentina. Diario Pregón. Argentina; 1971.

2. Distel FAA. Petroglifos posthispánicos y actuales en la Provincia de Jujuy. Anuario 13, Academia Nacional de Bellas Artes, Buenos Aires. $1985 \mathrm{a}$.

3. Distel FAA. Investigación sobre el arte rupestre hispano-indigena del NO de la República Argentina. Contribuciones al estudio del Arte Rupestre Sudamericano 3, Bolivia; 1992a.

4. Distel FAA. Pinturas rupestres posteriores a la conquista española en Jujuy: San Lucas Dep Valle Grande, Argentina. Contribuciones al estudio del arte rupestre sudamericano 3, Bolivia; $1992 \mathrm{~b}$.

5. Odina S. En torno a los tapados. Entregas del IT 12, 17 páginas, Argentina; 1981.

6. Axel N. The treasures of the Quebrada de Humahuaca. Lara Producciones. Argentina; 2001. p. 47.

7. Juan S. Epistemología y Metodología. Eudeba. Argentina; 1993. p. 413.

8. Claudia F. Juella, estudio folklórico. Jujuy Cultural 4, Argentina; 1975.

9. Sven O. Spiritual and political uses of rock engraving site and its imagery by san and Tswana peoples. South African Archaeological Bulletin. 1995;50(161):55-67.

10. Distel FAA. Tranca de los Diablos, rostros que contemplan desde lo alto. Boletín Asociación española Amigos de la Arqueología 21, Spain; 1985b. p. 1-18.

11. Distel FAA. Mapa arqueológico del Departamento de Tumbaya Paleoetnologica 3, Argentina; 1985c. p. 53.

12. Distel FAA. Catálogo del Arte Rupestre de Jujuy. Dunken. Argentina; 2001. p. 279. 